\title{
昭和 52 年度順天堂大学医学部共同生化研究室 研究報告会抄録
}

Annual Reports from Central Biochemical Laboratory

日 時：昭和52年9月 3 日（土）

場 所：順天堂大学 9 号館 1 番教室 (

\section{（講演発表）}

1. Mastomys に発生する carcinoid が産生する a mine の分析について

\section{消化器外科 ○鎌野俊紀, 岸野 洋}

Mastomys は, 腺胃飞 carcinoid を高率飞自然発生 し，その腫瘍は銀好性細胞で， histamine を産生する事 が知られている。そして我々は，前回は carcinoid を発 生した例で臟器䑚よび carcinoid 飞 histamine のほか 飞 serotonine を発生する事を営光組織招よび定量分析 そて確認した事を報告した．そこで今回は，この事を確 かめるために自然発生した carcinoid を carcinoid を発 生していない mastomys飞移植して各臟器の histamine serotonine を定量分析してみた.すると，移植腫瘍とは histamine はもちろんの事, やはり Serotonine を分析 し, また各臟器と抢いても histamine のほかと serotonine の増光ている事を確認した. よって, このcarcinoid は従来言われていた histamine の他飞 serotonine を分析できたことは，この carcinoid の多分泌能を有す る事が分かり, 今後人間の carcinoid と対此しながら研 究を進めて行きたい。

2. 腎不全における cyclic nucleotide の臨床的な らびに実験的研究

内 科 (腎臟) ○山崎博通, 小出 輝

腎不全飞招ける cyclic nucleotide の動態, 意義につ いて未だ不明の点が多いが，慢性腎不全患者执よび実験 的急性腎不全家鬼飞拄いて, 血漿 cAMP, cGMP の变 動と glucagon, PTH との関連飞ついて検討した. 慢性 腎不全患者では血漿 cAMP, cGMP はとも飞上暑して おり，ことに慢性透析症例飞扮いては著明であった。ま た，血嶈両 nucleotide は血清 creatinine と正相関を 示し, $\mathrm{Ccr}$ とは負の相関を示した. 透析例で血嶈 cAMP は血漿 glucagon と正相関を示し, cGMP は平均血圧 と正相関を示した. しかし，PTH はいずれの nucleotide とも相関を示さなかった．腎不全家鬼治特いても

〔Nov. 2，1977 受付〕
血漿両 nucleotide は, ともに上昇し, 血清 creatinine と正相関を示した. また glucagon は経過とともに上 昇傾向を示し，cAMP 間で正相関がみられた。組織内 nucleotideをみると，cAMPは腎皮質で減少して和り， cGMP は肝で増加していた。

3. 先天性代謝異常症のスクリーニング

小肾科○大塚親哉, 高橋 寛, 星野明彦, 箕輪富公, 岩崎 仁, 金子堅一郎, 高橋系一

昭和46年より昭和 52 年 6 月までと, 833 回の先天性代 謝異常症のスクリーニング検査を行なった. その結果, ロウ症候群 1 例, フェニルケトン尿症 2 例, シスチン尿 症 2 例, 本態性高脂血症 3 例, ゴーシェ病 1 例, モルキ 才症候群 1 例, ハーラー症候群 1 例, 特よび楓糖尿症 1 例を発見することができた。

今回, ガラクトース血症を疑った症例 2 例, 糖原病 1 型を疑った症例 1 例とついて, 種々検索をした.

4. 薬剂過敏性肝障害に関する研究，とくに劇症 肝炎例についての検討

内科（消化器）山口毅一, 北見啓之, 山田隆治, 橋本英明, 高桜芳郎, 飯島敏彦, 市川尚一, ○浪久利彦，橘 節子

現在までにリンパ球幼若化試験により, 起因薬剤を確 認し得た薬剤過敏性肝障害は約 250 例経験しているが, その中, 劇症肝炎で死亡したものは 7 例である.これら 症例の起因薬剤は，ハローセン, サルファ剂, 抗原物質, マイナートランキライザーであったが，3例は八ローセ ンによるすのであり，特に 2 回以上の麻醉が行なわれた あのが 2 例みとめられた， その発症機序について検討す ると，はじめは Tリンパ球とよる細胞障害であるが，過 敏性の圥進により antibody-dependent cell-mediated cytotoxicityを特こし, 次住 immune complex disease となり，全身性 Arthus 反応飞より死亡するものと考光 られ，最終段階飞扔いては自己免疫反応飞よる影響が強 く加味されるすのと考兄られた. 


\section{5. 高カロリー輸夜時の窒素バランスの測定} 消化器外科沢田芳昭, ○菊嶋慶昭, 佐藤 真 今回我々は, 年間高カロリ一輸液症例 120 例中, 34 例 そついて, 連日ミクロキエルダール法にて尿中窒素量を 測定し，投与窒素との窒素バランスに関し $2 \sim 3$ の知見 を得た. 体重 $\mathrm{kg}$ あたりの投与カロリーと窒素バランス の関係を見ると，36.7 Cal $/ \mathrm{kg}$ 以上で窒素バランスは正 となってくる. 次炕 $\mathrm{kg}$ あたりの投与アミノ酸 $\mathrm{g}$ と $\mathrm{N}-$ バランスの関係について見ると， $1.39 \mathrm{~g} / \mathrm{kg} /$ 日以上で窒 素バランスは正となってくる. また, 腹水貯溜の末期癌 患者でも十分なカロリ一投与にて正の窒素バランスを保 つことができる. 長期間経口摄取不能な, 或いは, 不適 当な患者飞対し, その栄養管理上高カロリ一輸液は有力 な手段である，特飞縫合不全時の蛋白合成飞関する情報 を得るには，窒素バランスを見ていくことは重要であ る.負の窒素バランスが連日続くような場合, あるいは 今迄正であったバランスが，負化傾くような場合，その 原因を知り, 高カロリ一輸液をより効果的飞施行する事 が重要であると思われる。

\section{6. 脳動脈瘤破裂に伴なう脳血管攣縮の基礎的} 臨床的研究

\section{脳神経外科 $\bigcirc$ 渡辺 博}

脳動脈瘤の破裂飞伴ない，発生する脳血管卛縮浽虚 血をもたらし，予後に多大な影響を与える. 本研究は， この脳血管攣縮の病因を明らかとすると同時に，脳血管 攣縮の発生飞伴って起こる病態の变動を脳組織自身の変 化, 血液凝固線溶動態の变動, さら飞, intravascular componentの変動等の面からとらえることにより, 脳虚 血性合併症治療の一助とすることを目的としたものであ る.

\section{7. 組織内酸性ムコ多糖体の組織化学的検索法 とその応用}

\section{内科（循環器）○岡田了三}

結合織の病的状態と酸性ムコ多糖体とは密接な関係に あることは, 従来よく知られて和り, aMPSの化学的定 量・定性測定法もほぼ確立している。しかし, aMPSの 組織内局在飞ついては組織化学的方法飞頼る他ななく, その定量・分画は難しいとされていた，著者らは, 組織 片を $0.5 \% \mathrm{CTAB} て ゙$ aMPS 固定後, 通常のパラフィ ン包埋薄切を行ない，精巣性括よびストレプトミセス・ ヒアルロニダーゼ，コンドロイチナーゼ AC，执よび $\mathrm{ABC}$ 溶液飞よる $\mathrm{aMPS}$ 消化後飞 AMPS 染色を行なっ て比色定量する新しい方法を開発し, 生化学的定量とよ
い相関を得た. 本方法による aMPS 分析を各種疾患剖 検例の結合織に行ない, マルファン症候群でCHS・AC, 抌よびHAの増量する 2 型を認め, 膠原病で炎症活性の 高い場合飞 CHS•AC, 不活性化飞つれて HA, CHS$\mathrm{ABC}$ 成分の増加を証明した. 動脈硬化病変でも aMPS 分画は微妙江変化し, CHS-B が硬化病巣中の線維症の 進展と強く相関している.

8. インシュリン低血糖による内因性ガストリ ン放出機序に関する実験的研究

消化器外科 ○塩野 潔, 渡部洋三, 清水 浩, 金沢 寛, 津村秀憲

雑種成犬を用いて正常犬, M.V. 犬, POB 犬， 6-OH DA 犬, T.V. 犬, S.P. 犬, T.V.+ S.P. 犬の各群 5 頭 ずつを作成して,インシュリン静注前・静注後, 10分每 K, 60分迄採血し, 血中ヒスタミン, 5-HT, N.E., ガ ストリンを測定した. 血中ヒスタミンは正常犬, M.V. 犬で上昇， 5-HT は全群で殆ど変動せず， N.E. は正常 犬, M. V. 犬, T.V. 犬で増加し, 交感神経遮断群で抑 制，ガストリンは T.V.+S.P. 犬を除く全群で増加して いた. インシュリン低血糖による内因性ガストリン放出 機序としては, 視床下部一迷走神経系以外飞下垂体一副 腎系のいわゆる交感神経系の関与がより大きく，ガスト リン放出の最終メディエーターとしてはヒスタミンが強 く疑方机る。

\section{（紙上発表）}

\section{1. 消化器癌と血墏シアール酸}

\section{消化器外科公木淳一郎, 渡部洋三}

悪性腫瘍患者の血嶈, 腹水, その他の体液や，直接腫 瘍組織中の sialic acid の増加を認める報告が散見され るが，私共はさらに，これを手術や化学療法の効果判 定, 転移, 再発の予知等, 臨床上飞応用することを検討 している. 血漿sialic acidの測定法は Warren の TBA 法㳊よった。健常者 (31例) の平均值 $45.0 \mathrm{mg} / \mathrm{dl}$ r対 乙早期胃癌 (14 例) 50.6 , 進行胃癌 (30 例) $65.1 \pm$ 13.1 , 大腸癌 $(9$ 例) $60.4 \pm 13.6$, 肝胆膵癌 ( 4 例) 76.8 , 良性疾患 (17例) は55.4 $11.1 \mathrm{mg} / \mathrm{dl}$ であり, 健 常者と進行胃癌の間飞は危険率 $1 \%$ 以下で, 健常者と大 腸癌の間飞は危険率 $1 \%$ 以下で，進行胃癌と良性疾患の 間飞は危険率 $2 \%$ 以下で，招の抢の有意の差が認められ る.

今後, さらと悪性疾患とsialic acidの関係を検討する とともと，各患者の長期 follow up とより興味ある知 見を得ると思われる。 


\section{2. $\mathbf{N}$-エチル-N $\mathbf{N}^{\prime}$-ニトロ-N-ニトロソグアニジン (ENNG) 投与による犬胃癌の発生について, 一第12報, ガストリンの併用一}

内科 (消化器) 栗原 稔, 泉嗣彦, 宮坂圭一, 白壁彦夫

われわれは，ENNG を固型飼料と浸漬して経口投与 することとよって犬胃に限局する癌を発生させる独自の 方法を昭和 43 年以来報告している（順天堂医学 19，579, 1968 ほか). 今回は, 田原らの方法 (医学のあゆみ92, 430-432，1975）を参考に ENNG とテトラガストリン の皮下注を併用した。

A. ビーグル犬 4 頭に $2 \%$ Tween 60 含有の ENNG $150 \mu \mathrm{g} / \mathrm{ml}$ を 8 力月間, 1 力月間休薬後 $200 \mu \mathrm{g} / \mathrm{ml} 2.5$ カ月間投与, 後半 4 カ月間ガストリン $5 \mu \mathrm{g} / \mathrm{kg}$ 週 2 回, その後， 2 カ月間ガストリン $5 \mu \mathrm{g} / \mathrm{kg} \times 2$ /日を併用した ところ, 投与直後 3 頭死亡. 698 日目飞幽門狭窄で死亡 した 1 頭には全周性の管状腺癌（深達度ss）があった。

B. ビーグル犬 4 頭飞 ENNG $150 \mu \mathrm{g} / \mathrm{ml} 1$ 力月間, $200 \mu \mathrm{g} / \mathrm{ml}$ を 7 カ月間投与, 3 カ月後よりガストリン $5 \mu \mathrm{g}$ $/ \mathrm{kg} /$ 日1. 5 カ月間, $5 \mu \mathrm{g} / \mathrm{kg} \times 2 /$ 日5力月間を併用した ところ，2頭は 13 力月以内に死亡. 610 日目死亡の 1 頭飞前庭部全周性の Ca. scirrhosum, 709日目死亡の 1 頭飞胃上部前壁の低分化腺癌 $(\mathrm{pm})$, 前庭部の管状腺癌 (sm)がみられた。

3. 肝細胞内収縮蛋白に関する研究, とくに肝 内胆汁うっ滞との関係について

内 科 (消化器) 黒田博之, 田村公平, 今成晴代, 吉田和朗, 小松郁俊, 浪久利彦

肝細胞内にも種々の収縮蛋白が存在することは近年報 告されているが，その意義林てはな和明らかでな い.これら收縮蛋白の中, とくに, actin like filament は heavy meromyosin を結合させると短り構造が みられ，その存在が明らかとされることから，肝内胆汁 うっ㴖のみられる症例の肝生梌橴本についてこの microfilament の消長を観察した. microfilament は黄疸発 生時飞は増加せず，むしろ黄疸が消失した時期飞招いて 増加を示すことから，胆汁うっ滞の発生機序の如何でな く, 胆汁うっ滞の期間飞よって左右されるものと考光ら れた。な牧, これら microfilament とついてビリルビ ン, 胆汁酸, その他物質の排泄との相関を検討し, その

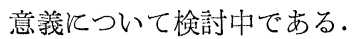

4. 肝の色素移送に関する研究，とくに血清蛋 白と ICG との結合について
内 科 (消化器) 小林教雄, 山城雄二, 及川洋子, 南部勝司, 浪久利彦 共同生化: 松井とみ子

血清蛋白は, Sephadex G200 でゲル洰過すると $3 ヒ ゚$ 一クにわかれるが，ICG は添加濃度によりその分布が ことなる.すなわち， $10^{-5} \mathrm{M}$ では $\beta$-lipoprotein のみ

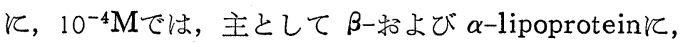
$10^{-3} \mathrm{M} て ゙ は ~ \beta-, \alpha$-lipoprotein と albumin 飞結合するこ とがみとめられ，色素と蛋白との結合とは優先順位が存 在することが確かめられた。 また血清蛋白と ICG Kつ いて平衡ゲル沪過法を行ない，その結合状態を観察する と, high affinity low capacity (K : $0.6221 \times 10^{3} 1 /$ mol, np : $\left.4.0977 \times 10^{-3} \mathrm{M}, \Delta \mathrm{F}^{\circ}-3.807 \mathrm{Cal} / \mathrm{M}\right)$ の群 $と$, low affiniay high capacity (K:0.0178 $\times 10^{3}$, $\left.\mathrm{np}: 16.2921 \times 10^{-3}, \Delta \mathrm{F}^{\circ}-1.703\right)$ 群がみられ，それぞ れ上記の lipoprotein群と, albumin と相当するあの と考光られたが，これら相互間飞も影響があり，その濃 度差によって結合状応がことなるすのと思考された。

\section{5. 抗腎血清ネフローゼラットにおける糸球体}

\section{基底膜の化学組成}

内科（腎臟）添田昇, 小出輝

今回は，抗腎血清ネフローゼラット(NTNラット) に 特ける系球体基底膜 (GBM) の化学組成飞ついて検討し た. NTN ラットの作製は抗ラット家鬼血清を用いた. $\mathrm{GBM}$ の分離精製法, アミノ酸, ヘキソサミン，䦽よび 糖の各分析法は前飞報告した方法飞よった.アミノ酸組 成では，4-ヒドロキシプロリン，グリシン，イソロイシ ン，呿よびシスチンの有意な減少，アスパラギン酸，ス レオニン, セリン, グルタミン酸, アラニン, ロイシ ン, チロジン, ヒドロキシリジン (OH-Lys), 特よびリ ジン (Lys) の有意な増加がみられた. ヒドロキシプロ リン(OH-Pro)/プロリン (Pro) 此, OH-Lys/Lys 比, 特よび OH-Pro+Pro は減少, OH-Lys+Lys は增 加を示した. 糖組成では, グルコサミン, ガラクトサミ ン呿よびフコースの有意な減少, シアル酸の增加がみら れたが，総糖量には有意な変化はなかった。

6. 高速液体クロマトグラフィーによる高血圧 患者尿中カテコールアミンの分析

内科（箵臟）平井朝子, 山下秀光, 小出 輝 種々の高血圧の発症機構として, カテコールアミン代 謝の翼常が推測されているが, 現在まで尿中, あるいは 血中カテコールアミンの信頼できる, 高感度の測定法は ない。 
著者らは, 現在尿中カテコールアミンの分析に高速液 体クロマトグラフィーを用い, 検知器として日本分光の 高感度蛍光光度計を使用して検討している. 強酸性陽イ オン交換樹脂カラム $(4.6 \phi \times 100 \mathrm{~mm})$, クエン酸リチウ 厶系緩衝液の 4 溶媒切換, 流速 $0.5 \mathrm{ml} / \mathrm{min}$, 圧力 $45 \mathrm{~kg}$ $/ \mathrm{cm}^{2}$, 温度 $55^{\circ} \mathrm{C}$ の条件で, ヒト尿中のドーパ，ノルア ドレナリン，アドレナリン，ドーパミンを定量しうるこ とを認めた.

また, 血中カテコールアミンの定量には, カテコール アミンを, catechol-o-methyltransferase と, ${ }^{3} \mathrm{H}$ methyl] S-adenosylmethionine 存在下飞 3-0-methyl 誘導体として, radiometric-enzymatic assayする方法 を検討中である。

7. 七上腎糸球体基底膜成分による補体の活性化 内科 (雫臓) 中山秀英, 小出 輝

著者らは, 腎疾患に特ける補体系とくに, alternative pathway, および $\mathrm{C} 3 \mathrm{NeF}$ につき研究を行ない, 補体シンポジウムに発表してきた.

今回, 腎糸球体局所での補体系の活性化を検討し, 腎 糸球体基底膜に補体活性化能の存在することを見いだし た.

ヒト糸球体基底膜の調製，拉よびこれからの酸性ムコ 多糖体の抽出は著者らの方法によった.

腎糸球体基底膜によるC 3 の変換は, 対照飞比し強 く, 濃度を増加させるにしたがい, より強い C 3 の变換 が認められた。

酸性ムコ多糖体 $5 \mathrm{mg} / \mathrm{ml}$ とよる C 3 の変探は, 糸球 体基底膜飞比してもより強く，また， GBG から GGG への変換も認められ，その変換はザイモザン $10 \mathrm{mg} / \mathrm{ml}$ より僅かと弱い程度であった．このことから，糸球体基 底膜による補体活性化は， alternative pathwayを介す ると考えられる。

\section{8. 自然発症高血圧ラットの血中および大動脈}

\section{壁の cyclic AMP と cyclic GMP}

内 科 (腎臟) 横松 守, 山崎博通, 小出 輝 本態性高血圧の成因として，血管平滑筋飞招けるカテ コールアミンのレセプターと, 密接な関係を有すると考 えられる血管壁 cyclic nucleotide の変化, 执よび血 漿 cyclic nucleotide の変化について検討した.

自然発症高血圧ラット（SHR）の生後 7 週, 12 週, 19週，30週の雄を用い，血獎，抒よび大動脈壁のcAMP 測定は competitive protein binding assay (Tovey 法), cGMP 測定は radioimmunoassayによった.
血漿 cAMP, 和よび cGMP は, SHR で有意飞上 昇していた. また, 大動脈 cAMP, cGMP 濃度は, 生 後12週のSHR では低下していたが，30週では両者とも 有意飞増加していた. 血漿 cAMP, cGMP と血圧の間 とは正の相関が認められた。

\section{9. クモ膜下出血に伴なう血液凝固線溶動態の 変動亡その対策}

脳神経外科渡辺 博, 小島純子, 石井昌三

我々は, 促来より脳動脈瘤破裂後の血液凝固線溶動態 飞関する一連の研究を行なっているぶ, 本報告では, 脳 動脈瘤破裂の脳血管攣縮飞随伴する脸虚血性合併症飞対 する risk factor として, 血漿 fibrinogen (Fbg) の変 動に着目し, 急性期に和ける凝固線溶動態の変動と, 脳 血管攣縮さらには予後との相関について述べた. 急性期 でのFbgの変動は正常範囲, あるいは500 mg/dl前後の上 昇にとどまるI群と， $600 \mathrm{mg} / \mathrm{dl}$ を越えて上昇する II 群 に分けられた. 後者では, 同時にantithrombin III, $\alpha_{2}-$ macroglobulin等飞も著明な変化をきたし, 血液粘度は 1.4〜1.8倍飞増大した. 脳血管攣縮との関連では，I群 の67\%が攣縮なし，あるいは“mild”な攣縮であるのに 対し，II群では全例が“moderate”以上の戀縮であり， 予後との相関では，I群の $92 \%$ までが社会復帰可能であ るのに対し， II群では $27 \%$ と両者間に明確な相異を認め た.また $\mathrm{Fbg}$ が600 mg/dl を越光る時点で, 神経症状 が急速に悪化する例が多く，このレベルが $\mathrm{Fbg}$ 上昇の critical point であり, Fbg 上昇が脳虚血性合併症の重 要な risk factor であることがわかった。

\section{0. 大脳皮質虚血時のエネルギー代謝変動の生 化学的研究}

脳神経外科 小林督志, 工藤吉郎, 石井昌三

脳外科領域に於いて日々遭遇する脳虚血状態に関する 検索は, 近年種々の領域で進められてきた. 我々は, 頸 動脈閉塞により容易に大脳領域の虚血を起こす事で知ら れている mongolian gerbil (和名：砂ネズミ)を使用 し， 1, 5,20,30 拈よび60分の ischemia がもたらす生化 学的変化と, 血流再開後 6 時間にわたる回復過程のそれ とそ, エネルギー代謝産物执よび Cyclic nucleotides 等の parameter 飞ついて対比検討した. ATP, P-Cr, glucose は, 虚血開始と共飞著明な減少を示し, 乳酸, $5^{\prime}$ AMP 等は急激偪加するが，その後は ischemia が延 長しても余り变化はない. Cyclic AMP は虚血初期に Control の13倍近く増加し，その後やや減少する。一方 血流再開後の変化を見ると， 5 分以下の虚血では，エネ 
ルギー代謝産物の再貯溜は，ほぼ完全に行なわれると反 し, 20 分以上の虚血群では glucose, P-Cr の異常過眝 溜や，ATP，グリコーゲン等の回復不全が認められた。 さらにCyclic AMP, Cyclic GMP 共飞血流再開後著明 な増加を示した.この様な回復過程と於ける代謝の混乱 状態は, より長い虚血を行なった群で, より強く発現す ることが分った。これ等変化の中で特に Cyclic nucleotides の代謝異常が虚血後の脳機能の回復を困難にして いる事が強く示唆された。

\section{1. 脳動脈瘤破裂に伴なう脳血管攣縮の原因 物質と攣縮緩解物質に関する研究}

脳神経外科 野中利房, 小島純子, 宮岡 誠, 渡辺 博, 石井昌三

我々は, 脳動脈瘤破裂後飞出現する脳血管攣縮飞関し て一連の実験を行なってきたが, 今回は,その原因物質と 攣縮緩解物質飞関して, 新しい知見を得たので報告した.

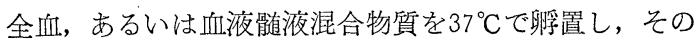
一部を犬脳底動脈の螺旋状標本 (in vitro)，あるいは犬 の脳底動脈露出飞よる直接添加 (in vivo) 飞より血管攣 縮を観察すると, 攣縮の程度は稃置時間の経過と共飞増 大し，7 日間睬置で最大の戀縮を示した。この 7 日間瞬置 試料を,Sephadex G-100 ゲル滤過，特よび CM cellulose イオン交換クロマト飞て精製し，吸光度，就よ゙゙ Disc 蛋白電気泳動江てその生化学的特性を検索すると, 攣縮原因物質が oxyhemoglobin，あるいはそれによく似 た生化学的特性をもつ polypeptideであることが判明し た. 一方, 攣縮緩解物質として生理的飞も血漿中に存在 し，へモグロビンをよく結合する特性を有する haptoglobin (Hp) 飞着目し, in vitro, in vivo の実験にて ヘモグロビンイよる攣縮を作製したのち，Hpを作用させ ると，血管攣縮が著明に改善される事実が判明した。 臨 床例飞扮いても脳動脈瘤の直達手術飞際し, 攣縮の存在 する血管に Hp を直接添加することとより，良好な結果 を得ている。

\section{2. 掌蹠膿疮症の免疫学的検索 (III)}

皮凨 科種田明生, 小川秀興, 宮崎宽明

我々は，本症の発症機序飞液性免疫が関与している事 を，百数十例の本症㭧者を検索し，その血清中飞掌距を 基質として用いた際酒，高抗体洒の抗細胞質抗体が検出 される事実より提唱してきた。一方本症の病変部には， PMN, リンバ球等の浸潤が高度飞認められる事より, 細

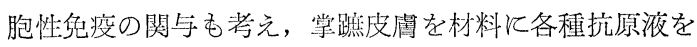
調整，これを用いて患者末梢血リンパ球に対する幼若化
度を検索してみた. 結果として, ツ反, DNCB 感作試 験では90\%の症例で陽性, PHA 添加による幼若化テス トではコントロール群と有為差なく細胞性免疫能飞特に 異常はみられないが，特異抗原を用いての検索では約 40 \%の症例飞有為の差で幼若化が認められた. 以上の結果 は, 本症が特飞掌蹠飞膿疮を好発する事の説明としても 興味深く, また, その機序に免疫が関与している可能性 も示唆させるものとも言えよう。

\section{3. ケラチン ( $\alpha$-fibrous Protein) の精製と}

\section{高分子（線維化）への機序について}

\section{皮 膚 科服部道廣, 小川秀興}

生体の線維性蛋白中筋蛋白 (ミオシン・アクチン), 杼 よびカラジェンの性状佂報告は多いが, 第 3 の ケラチンとついては極めて少ない，我々はこの上皮由来 のケラチンの精製, 拉よびその高分子化機構について検 索してみた. 人掌踫角層を材料に Urea 濃度, 塩濃度, -S-S-解離剂, 抽出条件(破壞度, 時間, 温度)等を組み 合せた結果, ケラチンはUreaのみでも他の条件を考え ればかなり高収率で抽出されるが， $\beta \mathrm{ME}$ を添加すると 急速飞抽出される事が明らかとなった． 25 万g 上清にく

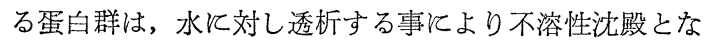
る.これを繰り返す事により精製され, 得られた不溶物 は電顕下とみごとな線維構造を認めた。 -S-S-化阻害剂 中でも高分子化は起こり, 電顕下, SDS gel 下でも対 照と比べ差は認められず, 従来漠然と（組織化学的飞） 高分子化は-SH の-S-S-化で起こるとの考光を否定する 結果となった。

\section{4. 表皮可溶性蛋白の性状について}

\section{皮膚科根木 信, 小川秀興}

表皮細胞の分裂は基底層のみで行なわれ，後は有䊂， 顆粒層と分化し, 角層中ではケラチンと呼ばれる 1 群の 不溶性高分子蛋白を形成する. しかしながら, この終末 産物も当初は可溶性低分子蛋白であると考光るのが常識 であろう.この低分子 (可溶性) から高分子 (不溶性) 蛋白への転換機構は今日の所明らかでない, 我々は, 低 分子蛋白対の lysine 基と glutamyl基をる- $\boldsymbol{r}$-glutamyllysine 結合でコバレントそ結び, 高分子化する酵素一 Transglutaminase-の存在と，その分離精製飞成功して いる. そこで, 今回はこの TGAse の触媒する可溶性蛋 白の同定を行なった。結果は, Tris-Acetate Buffer, PH 7.5 可溶分画より分子量 $3 \sim 7$ 万の蛋白群が $\mathrm{Ca}^{++}$, DTT 存在下飞高分子化していく事を見い出した. 現在この高分子蛋白和よび低分子前駆物質の性状を検索 
中である.

15. 皮膚の-SH 基とその-S-S-化について

$$
\begin{array}{r}
\text { 種田明生, 小川秀與, } \\
\text { (生化学) 関根隆光 }
\end{array}
$$

表皮細胞の分化伴う-SH 基の分布, 扔よび -S-S結合化への挙動を人表皮切片上で特異的飞染色乙 観察 した. 従来の方法は, 原理的飞特異性という点飞疑問があ る. 今回我々は-SH基飞特異的飞結合後蛍光を発するマ レイミド誘動試薬 DACM (Sekine-Kanaoka 試薬) を 用いてこれを行なった. 細胞膜内-SH基量は,角化て従い 減少, 逆飞細胞質乃至間の営光次次第飞増強, ため飞角 層は網目状飞染色された. この事は, 角層注遊離の-S $\mathrm{H}$ 基は殆どないとの従来の知見と異なり, 皮膚の防禦機 構を考える上で重要な知見と思われる．また，-S-S-結 合化はliving cell層では殆ど起こらず, 角層の移行部に 怙いて急激飞増加し, 且つそれは角層中細胞膜飞限局し ているとの知見を得た. この事は従来角層細胞内の高分 子蛋白（主としてケラチン）化は, -S-S-とよって起こ るとの定説に反し, これら-SHの-S-S-への転換は主と して細胞膜上で起こっている事を示唆するであるう.

\section{6. 天疮瘡抗体に対応する表皮細胞膜上抗原 構造について}

皮 虚 科森岡真治, 種田明生, 小川秀興

天疮瘡抗原の局在飞ついては, 近年かなりの部分が明 らかとなってきたが, 抗原の化学構造一殊飞その抗原性 制禦機構とついては尚不明である. 我々は, 重層扁平上 皮より本抗原の分離精製を試みたが, 頻回の実験結果は 本抗原活性は操作中急激牦われるという事であった。 そこで, 凍結切片上で抗原性保持能を各種条件下飞検索 してみた. 即ち, PBS, Tris Acetate buffer, エタノー ル, アセトン, エーテル, DMSO, Tritron-X 等を各種 温度, 特よび時間で反応させた後, 抗体結合能を検索し てみたところ, 従来 PBS で抽出可能とされた報告に反 し，これは著しく抗原性を失活させる事を見い出した. 次いで抗原性保持条件を種々検索した所, Phosphateは 失活させ $\mathrm{Ca}^{++}$呿よび- $\mathrm{SH}$ 保護剤添加はこれを保たせる 事が明らかとなった。また EDTA, NEM等は逆飞急速 失活を誘導する事も判明した.これらは生体での本抗原 性の制禦機構なかんずく発症機構を考える点でも重要な 知見と思われる.

\section{7. 天疮瘡抗体結合部の各種皮膚疾患における 変化について}

皮虚 科 榛沢信子, 種田明生, 小川秀興
天疮瘡患者血清中に認められる抗体は, 重層徧平上皮 膜面飞特異的飞結合するものである事は明らかとなって いる. そこで, 我々は本抗体, 牤よび同じく膜汶対して結 合能を有する PHA, Con A の3者をマーカーとして, 各種皮㿉疾患, 殊飞角化症, 招よび癌腫飞ついてこれらの 結合能を半定量的飞検索してみた. 結果, 有棘細胞癌で は正常と同じ結合能を示すもの1例, 結合能低下するす の3 例, 全く結合能を示さないすの 2 例であり, 細胞の 分化が高度なものほど反応性が保たれているとの所見を 得た. 就中, 1 例の未分化例でも天疮瘡抗体への結合能は 消失していたが, PHA, Co A への結合能は存在した. 一方基底細胞癌では全く結合能を示さなかった.これら の事より, 天疮癜抗体結合能と細胞の分化 (角化) との 関係はかなり密接なもので, かかる観点での既報の如 く, 癌化での膜変化は PHA, Con A 等の結合する糖蛋 白部分でよりも更に精密に天疮癜抗体結合能によって反 映されるものとの知見を得た。

\section{8. 天疮瘡抗原の加令による变化について}

皮眉 科越山陽二, 森岡真治, 小川秀興

天疮瘡抗体は，種を問わず重層扁平上皮浪の及反応す る抗体であり, 従って, その抗原は上皮細胞の特異性に 密接な関係がある事が示唆される，上皮のもつ特有な機 能分化一角化一を, 組織培養上でその膜レセプターとの 関連から追求することは興味ある事と思われるが，もう 1 つの方法は, 胎生上皮を日令飞よって材料として用い る事であろう，そこで，Ratを被検動物とし用い，胎生 日令, 括よび出生後の日令每に, その角化を扁平上皮上の 天疮瘡抗原の成熟度との相関関係を検索してみた. 胎生 10〜20日の間で角化は徐々に起こるが，それに相関した 抗体結合能の上昇が膜面でも認められ, 出生後は既飞成 熟したRat 上皮と同程度の抗体価を示し，これは角化は 出生後值ちに完成するとの形態学的知見と一致した. 現 在迄に結合能のほとんどない日令の上皮を組織培養し， その抗体価の上昇を試みている.

19. 慢性関節リウマチ患者血清中の胸腺由来の 液性因子について

内 科 (膠原病) 島田畯介, 村上嘉明, 山形寿太郎, 中沢孝子, 嶡 治言, 塩川優一

最近飞なり, 自己免疫疾患飞於いても, 胸腺の機能 そついて種々の方法を用いて検索されている. 自己免疫 疾患の病因を細胞性免疫という立場から考元て, B-cell とT-cellの割合の不均衡より成り立つ可能性が推定され る. 今回我々は, この仮定をもととして, BACHの方法 
飞基づいて膠原病疾患の患者血清中の胸腺由来の液性因 子 (TF) の活性を測定し, 合わせて Spontaneous Sheep red cell rosette testを用いて,T-cell の subpopulation を検索し, 慢性関節リウマチ, SLE らと於け る胸腺の関与を検討した.

〈方法> 対象患者は, RA, SLE, OA, ベーチェット DM, PSS である. 被検血清は, 血清分離し, アミコン CF 50 にてロ過し, 測定飞使用した. TFの定量は, 生 後 5 週令の $\left(\mathrm{C}_{57} / \mathrm{B}_{16}\right)$ マウスに対し胸腺摘除術を施行 後 8〜10日目に殺し, 脾細胞を分離して使用した. 各段 階希釈患者血清にて脾細胞を処理し，これにアザチオプ リンを最終濃度 $10 \mu \mathrm{g} / \mathrm{ml}$ となるよう加え $37^{\circ} \mathrm{C}, 90$ 分 ncubation 後 SRBC を加光, ロゼツト形式を測定し, アザチオプリンによって70〜80\%のロゼツト形成阻止を 持って, TF 活性と判定した. また， T-cell の subpopulation は従来の方法を用いた.

〈結果＞ 慢性関節リウマチに於いては TF 活性は比較 的高值を示し，SLE は低值を示す傾向があったが，治 療楽剤との関連もあり今回は測定結果の分析よりは, TF 測定方法の検討を行なった。

\section{0. 小児悪性腫瘍患者のアミノ酸代謝}

一腎芽腫症例の術前術後一
小児外科

長谷川史郎，平井慶徳，今井武治 藤原利男, 真田 裕

覀性腫瘍の生化学的特徵の基本は, 核酸タンパク代謝 の異常な元進に求められている。したがって, 生体て拉 ける悪性㯖瘍の存在は当然アミノ酸代謝にも大きな影響 を与えている事となる。このよろな観点から, 我々は, 小児期の外科的悪性腫瘍の生化学的補助的治療の開拓を 最終目標として, 種々の小児期外科的悪性腫瘍のアミノ 酸代謝とついて検討を行ないつつある.今回は, 督芽型 腎芽腫を有する小坚6例を対象とし, 術前術後の血漿了 ミノ酸の動態を観察した. 結果 : (1)術前の血漿中遊離ア ミノ酸濃度は, 腎芽腫早期例では著明飞低下して秥り, stage が進むとつれて上昇した. (2)繁芽腫早期例の術 前血漿アミノグラムは極めて類似した pattern を示し， Val, Leu, Met, Cys, Try などが著明飞減少していた。 しかし, stage IV 群のアミノグラムには一定傾向を認 めなかった. (3)腎芽腫早期例では腫瘍の摘出とよりアミ ノグラムは正常対称值晌って復帰傾向を示した. これ らの事実から, 我々は, 腎芽腫早期例飞挌いては, 生体 の腫瘍飞対する防禦機構として腫瘍の発育を制限するよ うな何らかの機序が存在することを推測し, 今後, さら 飞㭘索をすすめる予定である。 